DOI: 10.46340/eppd.2021.8.3.23

Dmytro Abrykosov

ORCID ID: https://orcid.org/0000-0002-9680-6177

Zaporizhzhya National University,

National Police, Department of Strategic Investigations in Chernihiv region, Ukraine

\title{
PROBLEMATIC ISSUES AND PROSPECTS \\ OF IMPROVEMENT OF THE LEGISLATION \\ ON PROTECTION OF PASSENGERS' RIGHTS \\ UNDER THE CONTRACT OF AIR TRANSPORTATION
}

\author{
Дмитро Абрикосов \\ Запорізький національний університет, \\ Національна поліція, УСР в Чернігівській області, Україна

\section{ПРОБЛЕМНІ ПИТАННЯ ТА ПЕРСПЕКТИВИ УДОСКОНАЛЕННЯ ЗАКОНОДАВСТВА ЩОДО ЗАХИСТУ ПРАВ ПАСАЖИРІВ ЗА ДОГОВОРОМ ПЕРЕВЕЗЕННЯ ПОВІТРЯНИМ ТРАНСПОРТОМ}

Civil law regulation of relations in the field of passenger transportation under the laws of Ukraine is "in the grip of strains", which were characteristic for the period before Ukraine's independence. The exception was the sphere of air transportation of passengers, where the influence of international norms in the field of regulation of civil aviation took place. A number of normative legal acts were adopted, in particular, the Air Code of Ukraine and several versions of the Rules of Air Transportation and Passenger and Luggage Services. However, the presence of violations of the rights of passengers under the contract of air transportation, certified in court decisions when considering disputes between air carriers and passengers, indicates the imperfection of the mechanism for ensuring the rights of the latter. A key element of such a mechanism should be an effective mechanism to protect the rights of the passenger under such an agreement.

The article stipulates that the formation of this is hindered by: imperfection in determining the legal status of the passenger, including due to the lack of enshrining a number of passenger rights currently defined in international instruments, in particular EU law, the lack of sufficient guarantees of the right to safety and the right to information; imperfection of legal regulation of the mechanism of protection of the rights of the passenger, in particular, concerning the order of protection of the violated rights and lawful interests and ways of their protection.

It is determined that the civil liability of the air carrier does not solve all issues of protection of passenger rights under the contract of air transportation, as it is aimed at influencing the behavior of the air carrier through the implementation of relevant functions of civil liability: prevention and compensation. The Institute for the Protection of Civil Rights is focused on ensuring the interests of the passenger. At the same time, it is based on the general provisions set out in Art. 16 of the Civil Code of Ukraine. With regard to the peculiarities of regulating transportation relations by acts of transport legislation, which have a special nature, not only the grounds and features of civil liability of the air carrier should be specified in the Air Code of Ukraine and the Rules of air transportation and passenger and luggage service, but also protection of violated rights, in particular, the right to refuse transportation and self-defense.

Keywords: passenger, contract of carriage of a passenger by air, safety, protection of passenger rights, procedure for protection of passenger rights, forms and methods of protection of passenger rights. 
Постановка проблеми. Національне законодавство у сфері правового регулювання перевезень пасажирів повітряним транспортом орієнтоване на поглиблену інтеграцію 3 правом ЄС та міжнародним законодавством у сфері діяльності цивільної авіації, що спеціалізується на перевезенні пасажирів.

Тому, в першу чергу, сприяє специфіка авіаційних перевезень, які здійснюються повітряними суднами не лише в національному просторі України, але й здебільшого, в міжнародному сполученні. Правове регулювання міжнародних повітряних перевезень пасажирів має свої традиції, зумовлені діяльністю міжнародних організацій, що забезпечують визначення правил перевезення пасажирів повітряним транспортом та забезпечення безпеки руху цивільних повітряних суден. Йдеться про правотворчу діяльність міжурядових організацій - IКАО та ІАТА. ІКАО було підготовлено Гаазький протокол 1955 р., Гвадалахарську конвенцію 1961 р., Гватемальський протокол 1971 р., Монреальский протокол 1975 р., як додаток до Чиказької конвенції. У них, як і в інших рекомендаціях, визначено діяльність пілотів, екіпажів літаків, операторів служби повітряного руху і наземних екіпажів, регламентовано вимоги щодо літаків та їх устаткування, аеронавігаційних карт тощо. На сьогоднішній день провідним актом стала прийнята в 1999 році Монреальська конвенція для уніфікації деяких правил міжнародних повітряних перевезень (IКАО) ${ }^{1}$. Цей акт забезпечує єдиний правовий режим на основі уніфікації міжнародних звичаїв договірного права повітряних перевезень.

В рамках ЄС прийнято Регламент (СС) № 261/2004 Свропейського Парламенту та Ради «Щодо встановлення загальних правил в галузі компенсації та сприяння пасажирам у разі відмови в посадці, відміни або тривалої затримки авіарейсу та про відміну Регламента (СЕС) № 295/91»². Останній створив основу забезпечення прав пасажирів за договором перевезення пасажира повітряним транспортом. Він орієнтований, здебільшого, на вирішення питань компенсацій у випадку типових порушень прав пасажирів. Втім, він не регламентує відносин на рівні визначення змісту договору перевезення пасажира повітряним транспортом, не визначає ідеальної моделі цих відносин, а лише вирішує питання компенсаційних виплат пасажирам перевізником, що $є$ важливою гарантією не лише захисту, а особливо, здійснення їх прав.

Звертає увагу, що жоден з актів, як міжнародних, так і національних не вирішує комплексно проблему як забезпечення прав пасажирів за договором перевезення пасажира повітряним транспортом, так і їх захисту у випадку порушення прав пасажира чи законних інтересів особи, що має намір чи бажання набути статусу пасажира шляхом укладання договору перевезення.

Це дає підстави для висновку, що механізм захисту прав пасажира за договором перевезення пасажира повітряним транспортом є фрагментарним, непослідовним та недостатньо ефективним, оскільки законодавство в першу чергу орієнтоване на забезпечення інтересів авіаперевізника, що $\epsilon$ тенденцією економічного протекціонізму, намаганням держави забезпечити функціонування транспортної системи та забезпечити поступальний розвиток економіки, тим самим залишаючи споживача-пасажира наодинці з перевізником-професіоналом, здатним використовувати недоліки транспортного законодавства в своїх інтересах. Проблем додали і нові виклики часу - зупинення авіаперевезень на підставі рішень органів державної влади в порядку здійснення карантинних заходів щодо запобігання поширення SARS COV2 (Covid 19). Окремі авіакомпанії відмовляли пасажирам в поверненні вартості коштів узв'язку з неможливістю виконання договору перевезення, посилаючись на дію обставин непереборної сили (форс-мажор), чи вимагаючи здійснити перебронювання на інші дати з тих же підстав. Більшість пасажирів виявилися неспроможними захистити свої права, тим більше, що реалізація претензійного порядку врегулювання спорів виявилася доволі складною, а право пасажира «бути почутим» часто просто ігнорується.

Аналіз останніх досліджень з тематики. Науковцями в сфері перевезень пасажирів було здійснено низку досліджень, присвячених правовому регулюванню перевезень пасажирів різними видами транспорту. Серед них дослідження О.М. Нечипуренка «Цивільно-правове регулювання перевезень таксі» (2008), А.О. Мінченка «Договір перевезення пасажира та багажу залізничним транспортом в Україні» (2011), Р.Б. Сірка «Відповідальність учасників цивільних правовідносин, що

\footnotetext{
${ }^{1}$ Монреальська конвенція для уніфікації деяких правил міжнародних повітряних перевезень, 1999 (IКАО). Офіиійний сайт Верховної Ради Украӥни <https://zakon.rada.gov.ua/laws/show/995_594\#Техt> (2021, травень, 28).

2 Регламент Свропейського Парламенту та Ради Щодо встановлення загальних правил в галузі компенсації та сприяння пасажирам у разі відмови в посадиј, відміни або тривалої затримки авіарейсу та про відміну Регламента (СЕС), 2004 (ЄС). Офіиійний сайт Верховної Ради Украӥни <https://zakon.rada.gov.ua/laws/show/994_912\#Text> (2021, травень, 28).
} 
виникають 3 перевезення вантажів, пасажирів та багажу залізничним транспортом, за законодавством України» (2012), У.П. Гришко «Захист прав споживачів транспортних послуг» (2017), Г.В. Цірат «Уніфікація норм міжнародного приватного повітряного права: сучасний стан та тенденції» (2019), I.C. Лукасевич-Крутник «Теоретичні засади правового регулювання договірних відносин 3 надання транспортних послуг у цивільному праві України» (2019), Г.В. Самойленка «Договір перевезення пасажира: теорія і практика забезпечення прав пасажира» (2021) та ін. Однак, вони не орієнтовані виключно на дослідження правовідносин та особливостей цивільно-правового регулювання перевезень пасажирів саме повітряним транспортом, а тим більше, вирішенню питань цивільноправового захисту прав пасажира за договором перевезення пасажира повітряним транспортом, хоча окремі з них, зокрема, I.С. Лукасевич-Крутник та Г.В. Самойленко торкалися контекстуально сфери повітряних пасажирських перевезень, їх нормативному та договірному регулюванню, правовим наслідкам порушення договору перевезення пасажира та прав і законних інтересів пасажира, включно цивільно-правової відповідальності перевізника та захисту прав і законних інтересів пасажира. Водночас, диференційованість відносин з надання транспортних послуг за видами транспорту, що зумовлене в першу чергу особливостями їх функціонування, визначає не лише специфіку та особливості правового регулювання цих відносин, але й правову природу таких правовідносин, що виникають за договором перевезення пасажира, зміст суб'єктивних прав та обов'язків сторін за договором та правові наслідки їх порушення. Нажаль, права пасажира за договором перевезення пасажира хоч і більшою мірою конкретизовані та забезпечені упорівнянні з іншими видами транспорту, проте, вони не забезпечені щодо здійснення та правового захисту в тій мірі, яка б повністю задовольняла потреби пасажира. Звичайно, відсутність конкретизації окремих прав пасажира, особливостей їх здійснення, допустимих законних підстав та порядку їх обмеження, а також ефективного механізму їх правового захисту ускладнює вирішення проблеми забезпечення захисту прав пасажирів. 3 іншого боку, пізнання причин, які зумовлюють порушення прав пасажира та низьку ефективність їх захисту є важливим з точки зору вирішення способів їх усунення, і в першу чергу, шляхом удосконалення чинного законодавства в сфері правового регулювання перевезень пасажирів повітряним транспортом.

Основний виклад. На сьогоднішній день основними джерелами правового регулювання перевезень пасажирів повітряним транспортом є Повітряний Кодекс України від 19.05.2011р.та Правила повітряних перевезень та обслуговування пасажирів і багажу ${ }^{1}$, затверджені Наказом Державної авіаційної служби України від 26.11. 2018 р. № 1239. В тексті Правил визначено, що вони розроблені та прийняті з урахуванням вимог Регламенту (СС) Європейського Парламенту та Ради від 05 липня 2006 року № 1107/2006 про права інвалідів та осіб з обмеженою рухливістю при використанні повітряного простору, Конвенції про права осіб з інвалідністю, Регламенту (ЄС) Європейського Парламенту та Ради від 11 лютого 2004 року № 261/2004 про запровадження загальних правил компенсації та допомоги пасажирам у разі відмови у перевезенні та скасування чи тривалої затримки рейсів, Регламенту Ради (СС) від 09 жовтня 1997 року № 2027/97 про відповідальність авіаперевізника у випадку інциденту, із змінами, внесеними Регламентом (ЄС) Європейського Парламенту та Ради від 13 травня 2002 року № 889/2002, Регламенту (СС) № 785/2004 Європейського Парламенту та Ради від 21 квітня 2004 року про вимоги до авіаперевізників та експлуатантів повітряних суден щодо страхування, Конвенції про уніфікацію деяких правил міжнародних повітряних перевезень, вчиненої 28 травня 1999 року в місті Монреалі, Загальних умов перевезень пасажирів і багажу, встановлених Міжнародною асоціацією повітряного транспорту («General Conditions of Carriage (passenger and baggage)»), резолюцій та рекомендованої практики Міжнародної асоціації повітряного транспорту (IATA), стандартів та рекомендованої практики Міжнародної організації цивільної авіації (ICAO).

Але чи $є$ забезпеченими права пасажира? Щодо пасажирів з інвалідністю, Правилами повітряних перевезень та обслуговування пасажирів і багажу закріплений обов'язок авіаперевізника приділяти особливу увагу потребам пасажирів з інвалідністю або з обмеженими фізичними можливостями та осіб, які їх супроводжують, а також потребам дітей, у тому числі тим, які подорожують без супроводу дорослих. Водночас, п. 12 Глави 1 Розділу VIII Правил визначає, що у випадку, якщо пасажир з інвалідністю або з обмеженою рухливістю прибуває до аеропорту з метою

\footnotetext{
${ }^{1}$ Наказ Про затвердження Авіаційних правил Украйни «Правила повітряних перевезень та обслуговування пасажирів і багажу, 2018 (Державна авіаційна служба України). Офічійний сайт Верховної Ради України <https://zakon.rada.gov.ua/laws/show/z0141-19\#Техt> (2021, травень, 28)
} 
здійснення повітряного перевезення, на яке він має бронювання, експлуатант аеропорту повинен забезпечити надання допомоги, зазначеної у пунктах 18, 19 цієї глави, за умови, що запит щодо допомоги під час перевезення особи з інвалідністю або з обмеженою рухливістю направлено авіаперевізником принаймні за 48 годин до часу вильоту рейсу, який зазначений у квитку. 3 цього слідує, що у випадку, якщо пасажир не сповістив завчасно експлуатанта про потребування допомоги, вона не $є$ обов'язковою для надання, а фактично, пасажир не зможе здійснити своє право на свободу пересування на недискримінаційній основі. Про необхідність закріплення права пасажира на мобільність та здійснення права на пересування на недискримінаційній основі зазначає в своєму дисертаційному дослідженні Самойленко Г.В ${ }^{1}$.

Формально Правилами повітряних перевезень та обслуговування пасажирів і багажу навіть передбачено правові наслідки безпідставної відмови пасажиру в перевезенні. Розділ XV Правил загалом присвячений правам пасажирів у разі відмови у повітряному перевезенні, скасування або затримки рейсів. Але норми цього розділу не стосуються випадків, коли пасажирові формально не було відмовлено в перевезенні, але через відсутність допомоги пасажир не зміг здійснити посадку та переліт. Формально це визначається як добровільна відмова пасажира від рейсу. I таких випадків доволі багато. За визначенням Сапельникової Г.А. в СС на ринку авіаперевезень пасажирів права пасажирів також доволі часто порушуються через відсутність чи низьку ефективність механізмів забезпечення прав пасажирів та їх захисту, внаслідок чого менше ніж половині пасажирів, які мають право вимагати допомоги, пропонується скористатися допомогою у випадку відмови у посадці та скасування або тривалої затримки рейсу; п'ята ж частина пасажирів взагалі не отримує відповідей на свої вимоги, а з числа осіб, які мають право на компенсацію, отримує лише близько $4 \%{ }^{2}$.

Доктор Джереміас Прасл, звертаючись до питання реформування прав пасажирів повітряних перевезень в ЄС звернувся до проекту Регламенту, запропонований 13 травня 2013 року Європейською комісією‥ Метою запропонованих змін було введення режиму максимального захисту прав споживачів повітряних послуг, проте, такий підхід призводив до здорожчання вартості транспортних послуг, що призводило до дискримінації авіаперевізників у порівнянні з перевізниками інших видів транспорту. Серед новел пропонувалося: до категорії «скасування рейсу» включити рейси, які відправилися з аеропорту, але змушені були змінити місце призначення або повернутися в аеропорт відправлення (справа Rodriguez v Air France ${ }^{4}$; закріплення наслідків затримки рейсу: «право на турботу»- надання пасажиру протягом затримки харчування, прохолодних напоїв, можливості скористатися засобами зв'язку та надання грошової компенсації пасажирам за затримку (не передбачена Регламентом № 261/2004, проте, право на таку компенсацію підтверджено в судових рішеннях); обов'язок надавати інформацію не пізніше, ніж після 30 хвилин затримки чи скасування рейсу (ст. 14 Регламенту № 261/2004 такої вказівки не містить); регламентація «затримки» рейсу в частині збільшення часу затримки рейсу, зі сплином якого пасажир отримує право на компенсацію: 5 годин на рейсах в межах ЄС, 9 годин для рейсів відстанню до 6000 км, 12 годин для рейсів понад 6000 км; закріплено право пасажира відмовитися від рейсу після 5 годин затримки. Варто звернутися i до рішення Суду СС у справі Folkerts v Air France5, яким аргументовано, що затримка рейсу визначається на час прибуття в останнє місце призначення, навіть якщо перший рейс відправився без затримки; право на ремаршрутизацію (право на отримання квитка на рейс інших авіаліній після 12-ти годинної затримки, щоправда, питання вартості такого квитка не було вирішене); право пасажира використати квиток лише в частині зворотного рейсу (та відповідну заборону перевізникові

\footnotetext{
${ }^{1}$ Самойленко, Г. В. (2021). Договір перевезення пасажира: теорія і практика забезпечення прав пасажира: дисертачія на здобуття наукового ступеня доктора юридичних наук. Одеса: НУ «Одеська юридична академія», 202.

${ }^{2}$ Сапельникова, Г. А. (2021). Асquis $Є С$ у сфері цивільної авіації та перспективи адаптації законодавства України у світлі підписання та набуття чинності Угоди про спільний авіаційний простір між Україною та ЄС. Міністерство юстиції України <https://minjust.gov.ua/azu_es_4_1> (2021, травень, 28).

${ }^{3}$ Prassl, J. (2013). Reforming Air Passenger Rights in the European Union. EUtopia law $<$ https://eutopialaw.wordpress.com/2013/03/21/reforming-air-passenger-rights-in-the-european-union/> (2021, травень, 28).

${ }^{4}$ European Union law (2011). Case C-83/10 Rodriguez $v$ Air France $<$ http://eurlex.europa.eu/LexUriServ/LexUriServ.do?uri=CELEX:62010CJ0083:EN:HTML> (2021, травень, 28). ${ }^{5}$ Eutopialaw (2013). Case C-11/11 Folkerts v Air France <http://eutopialaw.com/2013/03/18/sturgeon-revisited-yetagain-case-c-1111-air-france-v-folkerts/> (2021, травень, 28).
} 
відмови в посадці такому пасажиру) та ін. Окремі положення, зокрема щодо обмеження відповідальності авіаперевізника були сприйняті судами. Так, Суд ЄС усправі Case C-12/11 McDonagh vs Ryanair ${ }^{1}$ обмежив відповідальність авіаперевізника у випадку відміни рейсу, зобов'язавши надати пасажирам готель вартістю до 100 євро за ніч протягом максимум трьох ночей, крім випадків, коли йдеться про пасажирів з обмеженими можливостями, пасажирів 3 дітьми, вагітних жінок та інших пасажирів, які попередньо повідомили авіакомпанію, що вони потребують допомоги та особливого ставлення.

Серед типових порушень прав пасажирів вагоме місце займає затримка рейсу. За визначенням Г.В. Самойленка за таким порушенням на повітряному транспорті відшкодуванню підлягають лише реальні збитки з обмеженням меж відповідальності перевізника сумою 4694 СПЗ. Притому, він визнає, що Правилами повітряних перевезень та обслуговування пасажирів i багажу на авіаперевізника покладено обов'язок надання допомоги пасажиру при затримці рейсу (Глава 4 Розділу XV Правил) ${ }^{2}$. Така допомога включає у випадку відкладання виконання затриманого рейсу на наступний день: надання пасажирам номерів у готелі, харчування та забезпечення трансферу за маршрутом аеропорт - готель - аеропорт. Якщо ж затримка рейсу перевищує п'ять годин, пасажирам має бути запропоновано продовжити подорож або повернути вартість квитків i забезпечити зворотний рейс до початкового пункту відправлення за першої можливості або запропонувати новий маршрут. Такий підхід, закріплений в національних авіаційних Правилах, загалом відповідає Регламенту (СС) Європейського Парламенту та Ради від 11 лютого 2004 року № 261/2004 про запровадження загальних правил компенсації та допомоги пасажирам у разі відмови у перевезенні та скасування чи тривалої затримки рейсів.

В частині застосування міжнародних механізмів захисту прав пасажира існує дискусія щодо співвідношення положень Регламенту ЄС № 261/2004 та Монреальської конвенції 1999 р.

Так, Г.В. Цірат визначає, що на думку окремих науковців положення Регламенту (СС) 261/2004 порушують норми Монреальської конвенції. Так, Димпсі вважає неприпустимим для ЄС, який $є$ підписантом Монреальської конвенції, встановлювати власний правовий режим щодо окремих сфер авіаційної діяльності ${ }^{3}$. Дійсно, такий підхід може викликати протиріччя та правові колізії. Так, на їі переконання має місце різне змістовне навантаження категорії «затримка» за Правилами повітряних перевезень та обслуговування пасажирів і багажу та Монреальською конвенцією 1999 р. Визначаючи, що українське законодавство поділяє невиконання та неналежне виконання, то конвенція регулює лише питання затримки як неналежного виконання. 3 цього вона робить висновок, що нечітке визначення різниці між затримкою та невиконанням в українському праві може мати наслідком можливість обрання перевізником режиму відповідальності за Правилами, а не за Монреальською конвенцією. Дискусія щодо протиріч у застосуванні положень Монреальської конвенції 1999 року та Регламенту (СС) 261/2004 наразі вирішено на користь допустимості одночасного застосування обох актів. Так, у справі C-344/04 Міжнародна асоціація повітряного транспорту та Європейська асоціація низьких тарифів авіаперевезень проти Департаменту транспорту Суд СС підтвердив, що передбачені Регламентом з метою досягнення мети посилення захисту пасажирів, рейси яких скасовані або підлягають тривалій затримці, сумісні з Монреальською конвенцією та не порушують принцип пропорційності ${ }^{4}$.

Висловлюємо точку зору, що український варіант версії Монреальської конвенції для перевезень українськими авіаперевізниками, закріплений у Правилах повітряних перевезень пасажира і багажу являє собою модернізований частково варіант Монреальської Конвенції 3 «орієнтацією» на Регламент № 261/2004. Такий підхід є вимушеним компромісом, що має на меті

\footnotetext{
${ }^{1}$ Court of Justice of the European Union (2012). Case C-12/11 McDonagh v Ryanair <http://curia.europa.eu/jcms/upload/docs/application/pdf/2012-03/cp120032en.pdf> (2021, травень, 28).

${ }^{2}$ Самойленко, Г. В. (2021). Договір перевезення пасажира: теорія і практика забезпечення прав пасажира: дисертація на здобуття наукового ступеня доктора юридичних наук. Одеса: НУ «Одеська юридична академія», 325.

${ }^{3}$ Цірат, Г. В. (2012). Регулювання затримки рейсу за Монреальською конвенцією 1999 року та Правилами перевезення пасажирів і багажу. Держава і право, 56, 463.

${ }^{4}$ Europeansources (2006). Judgement in Case C-344/04. International Air Transport Association and European Low Fares Airline Association v Department for Transport <https://www.europeansources.info/record/judgement-in-casec-344-04-international-air-transport-association-and-european-low-fares-airline-association-v-department-for-transport/> (2021, травень, 28).
} 
забезпечення входження України в систему повітряного транспорту СС у сфері перевезень пасажирів і багажу повітряним транспортом та одночасно в систему міжнародних авіаперевезень пасажирів, які протирічать один одному в частині критеріїв вибору пріоритету сприяння захисту прав пасажира в частині компенсацій йому авіаперевізником шкоди, завданої скасуванням рейсу або тривалою його затримкою, або ж, вибору пріоритету безпеки пасажира, яке супроводжується полегшенням «режиму відповідальності авіаперевізника» через закріплення звільнення його від відповідальності за умови виконання ним усіх можливих заходів, спрямованих на недопущення такої шкоди.

Поставимо питання: які наслідки затримки рейсу чи затримки доставки пасажира до пункту призначення передбачають Правила повітряних перевезень пасажирів і багажу? Компенсації пасажирам у разі затримки рейсу Правилами не передбачені. Разом з тим, в Главі 5 Розділу 27 Правила закріплюють, що відповідальність перевізника за шкоду, заподіяну внаслідок затримки під час перевезення пасажирів будь-яких рейсів, обмежується сумою 4694 СПЗ стосовно кожного пасажира. Мова йде у даному випадку про обмеження відповідальності за завдану пасажиру шкоду. Виглядає досить дивно - суми компенсацій не встановлено, тобто компенсація відсутня, але якщо вона буде мати місце, - то їі розмір не повинен перевищувати 4694 СПЗ (за Правилами повітряних перевезень пасажирів і багажу); 4150 СПЗ за Монреальською конвенцією 1999 р. Який сенс взагалі тоді встановлювати граничний розмір таких збитків? Чому граничний розмір відповідальності авіаперевізника за законодавством України та Монреальською конвенцією різняться? Ст. 19 Монреальської Конвенції лише передбачає правила щодо затримки пасажира: перевізник несе відповідальність за шкоду, заподіяну внаслідок затримки в повітряному перевезенні пасажирів, багажу або вантажу. Однак перевізник не несе відповідальності за шкоду, заподіяну внаслідок затримки, якщо доведе, що він, його службовці та агенти вжили всіх заходів, які могли б бути необхідними для того, щоб уникнути шкоди, або що для нього чи для них було неможливо вжити таких заходів ${ }^{1}$.

Вбачається, що Монреальська Конвенція 1999 р. містить більш лояльний підхід до визначення винуватості перевізника, аніж українські Правила повітряних перевезень пасажирів і багажу. Вочевидь, Конвенція базується на критерії добросовісності, розумності, та невинуватості перевізника при вжитті ним всіх можливих з необхідних заходів, натомість законодавство України, включаючи ЦК України, виходить з принципу необхідності доказування вини перевізника (що стосується прострочки в доставці пасажира), а останнього, - щодо його невинуватості, де критерієм звільнення від відповідальності виступає дія обставин непереборної сили, несправність транспортного засобу, або інших обставин, які не залежали від перевізника (ч. 1 ст. 922 ЦК України) 2 .

Заслуговує на увагу позиція Остроумова М.М., який в своєму дисертаційному дослідженні висловив позицію (п. 16), що визнання вини перевізника як підстави його відповідальності за недотримання термінів перевезення, в якості непорушного принципу правового режиму міжнародних повітряних перевезень, $є$ умовою підвищення його відповідальності за життя і здоров'я пасажирів, незбереження багажу і вантажу. Тому спроби розглядати питання дотримання термінів перевезення у відриві від проблем безпеки людей при оцінці поведінки перевізника не $є$ виваженим підходом ${ }^{3}$.

Що стосується інших видів порушень договору перевезення пасажирів та багажу повітряним транспортом, Правила встановлюють, що у випадку відмови пасажирам у перевезенні проти їхньої волі, перевізник має виплатити їм компенсацію у таких розмірах: 250 євро - для рейсів дальністю до 1500 кілометрів; 400 євро - для рейсів дальністю від 1500 до 3500 кілометрів; 600 євро - для рейсів дальністю понад 3500 кілометрів. Цікаво, що ці суми компенсацій встановлено саме Правилами повітряних перевезень пасажирів і багажу, в той час, коли Монреальські правила подібних сум компенсацій взагалі не містять. Вони визначені ст. 7 Регламенту ЄС № 261/2004. Аналіз українських Правил повітряних перевезень пасажирів і багажу свідчить, що вони містять ті самі суми компенсацій, які передбачено ст. 7 Регламенту СС № 261/2004, однак положення, які містять обмеження

\footnotetext{
${ }^{1}$ Монреальська конвенція для уніфікації деяких правил міжнародних повітряних перевезень, 1999 (IКАО). Офіиійний сайт Верховної Ради України <https://zakon.rada.gov.ua/laws/show/995_594\#Техt> (2021, травень, 28). ${ }^{2}$ Цивільний кодекс України, 2003 (Верховна Рада України). Офіційний сайт Верховної Ради Украӥни $<$ https://zakon.rada.gov.ua/laws/show/435-15\#Text> (2021, травень, 28).

${ }^{3}$ Остроумов, Н. Н. (2013). Проблемы унификации и совершенствования правового режима международных воздушных перевозок: автореферат дисертации на соискание научной степени доктора юридических наук. Москва: МГИМО, 23.
} 
відповідальності авіаперевізника на його користь у порівнянні з інтересами пасажира, які закріплено в ст. 922 ЦК України щодо підстав звільнення перевізника від цивільної відповідальності, фактично нівелюють зміст та дух зазначеного Регламенту, чим де-факту встановлюють режим Монреальської конвенції 1999 р.

Нагадаємо, ст. 922 ЦК України серед підстав звільнення перевізника від відповідальності за затримку в доставці пасажира визначає непереборну силу, усунення несправності транспортного засобу, яка загрожувала життю або здоров'ю пасажирів, або інших обставин, що не залежали від перевізника. Вбачаємо, що авіаперевізник завжди може апелювати до зумовленості затримки вильоту чи доставки пасажира обставинами, пов'язаними з несправністю транспортного засобу, яка загрожувала життю або здоров’ю пасажирів, а тим більше «інших обставин, які не залежали від перевізника». Погодимося з позицією Г.В. Цірат, що Правила надають можливість українським перевізникам тлумачити як надзвичайні обставини технічні проблеми, що можуть бути наслідком неналежного технічного утримання літака, що прямо закріплено в п. 5 гл. 4 Розділу XVIII. Відтак, суд трактуватиме технічну несправність як надзвичайну обставину та звільняти перевізника від відповідальності ${ }^{1}$.

Висновки. Наразі Україною, яка приєдналася до Монреальської конвенції 1999 року, досягнуто певний компроміс в Правилах повітряних перевезень пасажирів і багажу за наявності певного протистояння між правом СС в цій сфері та зазначеною конвенцією, зумовленого намаганням права ЄС посилити відповідальність авіаперевізників перед пасажирами, а Монреальською конвенцією 1999 р. навпаки, мотивувати авіаперевізників до вжиття заходів безпеки. Правила повітряних перевезень пасажирів і багажу України увібрали положення Регламенту СС щодо компенсації пасажирам за шкоду, завдану тривалою затримкою рейсу, що слугує забезпеченню прав пасажира та визначеності механізму захисту прав пасажира за порушення строку його доставки. Водночас, положення ст. 922 ЦК України підлягають перегляду в частині уточнення критеріїв підстав звільнення перевізника від відповідальності за затримку в доставці пасажира, в тому числі щодо конкретизації «інших обставин, які не залежали від перевізника».

3 погляду на особливості регулювання відносин 3 перевезення актами транспортного законодавства, які мають спеціальний характер, не лише підстави та особливості цивільно-правової відповідальності авіаперевізника мають бути конкретизовані в Повітряному кодексі України та Правилах повітряних перевезень та обслуговування пасажирів i багажу, але й особливості застосування окремих способів захисту порушених прав, зокрема, право на відмову від перевезення, в т.ч. як наслідку істотного порушення умов договору, зокрема, тривалої затримки рейсу, в т.ч. внаслідок застосування карантинних заходів по запобіганню захворювань (приміром, SARS CoV2) без фінансових втрат для пасажира та здійснення самозахисту.

\section{References:}

1. Monrealska konventsiia dlia unifikatsii deiakykh pravyl mizhnarodnykh povitrianykh perevezen, 1999 (IKAO). [Montreal Convention for the Unification of Certain Rules for International Carriage by Air, 1999 (ICAO)] Ofitsiynyy sayt Verkhovnoyi Rady Ukrayiny [Official site of the Verkhovna Rada of Ukraine] <https://zakon.rada.gov.ua/laws/show/995_594\#Text> (2021, May, 28). [in Ukrainian].

2. Rehlament Yevropeiskoho Parlamentu ta Rady «Shchodo vstanovlennia zahalnykh pravyl v haluzi kompensatsii ta spryiannia pasazhyram u razi vidmovy v posadtsi, vidminy abo tryvaloi zatrymky aviareisu ta pro vidminu Rehlamenta, 2004 (ES) [Regulation of the European Parliament and of the Council On laying down general rules on compensation and assistance to passengers in the event of denied boarding, cancellation or long delay of a flight and repealing Regulation, 2004 (EU)]. Ofitsiynyy sayt Verkhovnoyi Rady Ukrayiny [Official site of the Verkhovna Rada of Ukraine] <https://zakon.rada.gov.ua/laws/show/994_912\#Text> (2021, May, 28). [in Ukrainian].

3. Samoylenko, G. V. (2021). Dohovir perevezennia pasazhyra: teoriia i praktyka zabezpechennia prav pasazhyra [The contract of carriage of the passenger]: dysertatsiya na zdobuttya naukovoho stupenya doktora yurydychnykh nauk [dissertation for the degree of Doctor of Laws]. Odessa: NU "Odessa Law Academy". [in Ukrainian].

4. Sapelnykova, H. A. (2021). Acquis YeS u sferi tsyvilnoi aviatsii ta perspektyvy adaptatsii zakonodavstva Ukrainy u svitli pidpysannia ta nabuttia chynnosti Uhody pro spilnyi aviatsiinyi prostir mizh Ukrainoiu ta YeS [EU acquis in the field of civil aviation and prospects for adaptation of Ukrainian legislation in the light of the signing and entry into force of the Agreement on the Common Aviation Area between Ukraine and the EU] <https://minjust.gov.ua/azu_es_4_1> (2021, May, 28). [in Ukrainian].

\footnotetext{
${ }^{1}$ Цірат, Г. В. (2012). Регулювання затримки рейсу за Монреальською конвенцією 1999 року та Правилами перевезення пасажирів і багажу. Держава і право, 56, 464.
} 
5. Prassl, J. (2013). Reforming Air Passenger Rights in the European Union. EUtopia law $<$ https://eutopialaw.wordpress.com/2013/03/21/reforming-air-passenger-rights-in-the-european-union/> (2021, May, 28). [in Ukrainian].

6. Eur-Lex (2011). Case C-83/10 Rodriguez v Air France <https://eur-lex.europa.eu/legal-content/EN/TXT/?uri= CELEX\%3A62010CJ0083> (2021, May, 28). [in English].

7. Eutopialaw (2013). Case C-11/11 Folkerts v Air France <http://eutopialaw.com-/2013/03/18-/sturgeon-revisitedyet-again-case-c-1111-air-france-v-folkerts/> (2021, May, 28). [in English].

8. Curia.Europa (2012). Case C-12/11 McDonagh v Ryanair <http://curia.europa.eu/jcms/upload/docs/application/pdf/2012-03/cp120032en.pdf> (2021, May, 28). [in English].

9. Tsirat, G. V. (2012). Rehuliuvannia zatrymky reisu za Monrealskoiu konventsiieiu 1999 roku ta Pravylamy perevezennia pasazhyriv i bahazhu [Regulation of flight delay under the 1999 Montreal Convention and the Rules of Carriage of Passengers and Baggage]. Derzhava i pravo [State and law]. [in Ukrainian].

10. Europeansources (2006). Judgement in Case C-344/04. International Air Transport Association and European Low Fares Airline Association v Department for Transport <https://www.europeansources.info/record/judgementin-case-c-344-04-international-air-transport-association-and-european-low-fares-airline-association-v-departmentfor-transport//> (2021, May, 28). [in English].

11. Nakaz pro zatverdzhennia Aviatsiinykh pravyl Ukrainy Pravyla povitrianykh perevezen ta obsluhovuvannia pasazhyriv i bahazhu, 2018 (Derzhavna aviatsiina sluzhba Ukrainy) [The Order about the statement of Aviation rules of Ukraine "Rules of air transportations and service of passengers and luggage", 2018 (The State aviation service of Ukraine). Ofitsiynyy sayt Verkhovnoyi Rady Ukrayiny [Official site of the Verkhovna Rada of Ukraine] <https://zakon.rada.gov.ua/laws/show/z0141-19\#Text>. (2021, May, 28). [in Ukrainian].

12. Tsyvilnyi kodeks Ukrainy, 2003 (Verkhovna Rada Ukrainy) [The Civil Code of Ukraine, 2003 (Verkhovna Rada of Ukraine)]. Ofitsiynyy sayt Verkhovnoyi Rady Ukrayiny [Official site of the Verkhovna Rada of Ukraine] <https://zakon.rada.gov.ua/laws/show/435-15\#Text> (2021, May, 28). [in Ukrainian].

13. Ostroumov, N. N. (2013). Problemy unifikaczii i sovershenstvovaniya pravovogo rezhima mezhdunarodnykh vozdushnykh perevozok [Problems of unification and perfection of a legal mode of the international air transportations]: avtoreferat dissertatsii na soiskaniye nauchnoy stepeni doktora yuridicheskikh nauk [the dissertation author's abstract for the scientific degree of Doctor of Law]. Moscow: MGIMO [in Russian]. 